JAMP: Jurnal Adminitrasi dan Manajemen Pendidikan

Volume 1 Nomor 4 Desember 2018, Hal : 410-418

Tersedia Online di http://journal2.um.ac.id/index.php/jamp/

ISSN 2615-8574 (online)

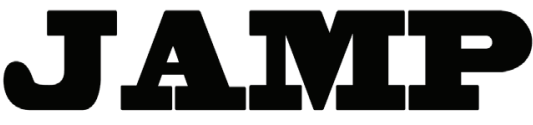

JURNAL ADMINISTRASI DAN MANAJEMEN PENDIDIKAN

\title{
BUDAYA SEKOLAH BERBASIS KETARUNAAN DALAM PEMBENTUKAN KARAKTER PESERTA DIDIK
}

\author{
Widyaning Rachmawati \\ Djum Djum Noor Benty \\ Raden Bambang Sumarsono
}

widyaningr31@gmail.com

Universitas Negeri Malang, J1 Semarang 5 Malang 65145

\begin{abstract}
: the purpose of this research to describe: (1) the form of culture, (2) cultural excellence, (3) the process formation of student character, (4) supporting factors of cultural implementation, (5) inhibiting factors of cultural implementation and (6) solutions made in overcome the barriers of "ketarunaan" based culturein forming student character. This study uses a qualitative approach, with a case study research at SMK Negeri 13 Malang. Data collection uses interview, observation, and documentation techniques. In analyzing data, the techniques used are reduction, data display and conclusion drawing. The results of this study are: (1) the form of "ketarunaan" culture consists of akamedic culture, social culture and democratic culture; (2) cultural excellence includes benefits obtained by internal and external parties; (3) the process of character building takes place through the implementation of school culture accompanied by elements of supporting the implementation of culture; and (4) supporting factors, inhibiting factors and solutions made in overcoming obstacles to the implementation of school-based learning culture which consists of internal and external parties.
\end{abstract}

Key-Words: school culture, "ketarunaan", students character

\begin{abstract}
Abstrak: Penelitian ini bertujuan untuk mendeskripsikan: (1) bentuk budaya, (2) keunggulan budaya, (3) proses pembentukan karakter peserta didik, (4) faktor pendukung pelaksanaan budaya, (5) faktor penghambat pelaksanaan budaya dan (6) solusi yang dilakukan dalam mengatasi hambatan budaya sekolah berbasis ketarunaan dalam pembentukan karakter peserta didik. Penelitian ini menggunakan pendekatan kualitatif, dengan racangan penelitian studi kasus di SMK Negeri 13 Malang. Pengumpulan data menggunakan teknik wawancara, observasi, dan dokumentasi. Dalam menganalisis data, teknik yang digunakan yaitu reduksi, display data dan penarikan kesimpulan. Hasil penelitian ini yaitu: (1) bentuk budaya sekolah berbasis ketarunaan terdiri dari budaya akademik, budaya sosial dan budaya demokratis; (2) keunggulan budaya meliputi keuntungan yang diperoleh pihak internal dan eksternal; (3) proses pembentukan karakter berlangsung melalui pelaksanaan budaya sekolah disertai dengan elemen penunjang pelaksanaan budaya; dan (4) faktor pendukung, faktor penghambat dan solusi yang dilakukan dalam mengatasi hambatan pada pelaksanaan budaya sekolah berbasis ketarunaan terdiri dari pihak internal dan eksternal.
\end{abstract}

Kata Kunci: budaya sekolah, ketarunaan, karakter peserta didik

Sekolah merupakan suatu bentuk organisasi yang mempunyai budaya tersendiri dari sistem yang utuh dan khas. Kekhasan budaya sekolah tidak lepas dari visi dan proses pendidikan yang berlangsung. Suatu sekolah dapat membentuk dan mengatur budaya yang ada, karena pembentukan dan manajemen budaya sekolah yang baik akan mendukung terciptanya sekolah yang efektif. Ketarunaan merupakan salah satu 
budaya yang dapat diterapkan di perguruan tinggi atau sekolah, lebih tepatnya Sekolah Menengah Atas/ Kejuruan (SMA/K) karena usia yang dinilai sudah cukup matang.

Ketarunaan merupakan sistem pendidikan yang dapat dijumpai di beberapa Perguruan Tinggi, SMA, dan SMK di Indonesia. Menurut Suryanto (2016) ketarunaan merupakan suatu sistem pendidikan yang menerapkan prinsip militer dengan tujuan membentuk karakter peserta didik, akan tetapi penerapan prinsip bukanlah prinsip murni militer. Berdasarkan pendapat tersebut, sekolah berbasis ketarunaan memiliki makna sebagai sistem pendidikan yang menerapkan prinsip-prinsip dasar militer. Prinsip yang diterapkan bukanlah militer murni akan tetapi dasar taruna (kegiatan pelatihan-pelatihan) yang digunakan dalam militer. Tujuannya adalah untuk menanamkan karakter, khususnya karakter kedisiplinan dan pembentukan kepribadian yang baik pada peserta didik. Pelaksanaannya mampu mencegah dan mengatasi penyimpangan pada kepribadian anak sehingga anak dapat berkembang dengan baik. Sekolah dengan basis ketarunaan dalam kesehariannya, secara fisik memiliki ciri tersendiri.

Salah satu sekolah di Kota Malang yang menerapkan budaya sekolah berbasis ketarunaan adalah SMK Negeri 13 Malang. Dalam sekolah ini ketarunaan diterapkan sejak didirikannya sekolah pada Tahun Ajaran 2012/2013. Lembaga pendidikan ini merupakan salah satu Sekolah Menengah Kejuruan di Kota Malang dengan basis ketarunaan untuk diterapkan sebagai budayanya. Budaya ketarunaan yang diterapkan merupakan kehendak dari sekolah dan berbeda dengan Sekolah Menengah Atas berbasis ketarunaan lain di Kota Malang. Menurut Ibu Any Yustiani, M.Pd. selaku guru di SMK Negeri 13 Malang:"Itu dari internal, jadi kepala sekolah menghendaki sekolah berbasis taruna. Sehingga berbeda dengan di SMA 10. Kalau itu pemerintah yang membuat sekolah itu berbasis ketarunaan, dengan fasilitas yang berbeda. Berbeda antara taruna sana dengan taruna sini, karena kita membuat sendiri sistem tarunanya." (W/F1/G/090022018)

Suasana taruna sangat kental terasa pada lingkungan sekolah. Dalam setiap kegiatan di lingkungan sekolah, penyebutan bagi peserta didik adalah taruna dan taruni. Tidak hanya berseragam layaknya personel militer, peserta didik juga bersikap dan memiliki daya tarik yang karismatik. Lingkungan belajar peserta didik di SMK Negeri 13 Malang terasa tenang dan asri. Suasana sejuk dan tanpa kebisingan menjadi faktor pendukung agar peserta didik mampu berkonsentrasi lebih pada pembelajaran dan kegiatan di sekolah. Lokasi di dalam sekolah juga mampu menjadi sarana yang baik untuk peserta didik dalam melatih fisik menjadi lebih baik, hal ini dikarenakan kondisi jalan yang berbukit, untuk menuju satu tempat ke tempat lain warga sekolah harus melalui tanjakan dan turunan. Tempat belajar peserta didik juga tampak bersih serta tertata rapi, meskipun pegawai kebersihan hanya berjumlah dua orang, yang mendasari kebersihan lingkungan sekolah ini karena adanya kerja bakti setiap bulannya, selain itu adanya aturan hukuman berupa membersihkan kebun apabila terjadi pelanggaran.

Studi pendahuluan yang dilakukan oleh peneliti menunjukkan bahwa peserta didik berada dalam budaya sekolah yang disiplin. SMK Negeri 13 Malang merupakan sekolah berbasis taruna yang bekerjasama dengan Angkatan Laut (AL) tepatnya Pangkalan TNI AL (Lanal). Bukan hanya menekankan pada kedisiplinan, SMK Negeri 13 Malang juga membentuk karakter peserta didik melalui peningkatan keimanan dan ketaqwaan terhadap Tuhan Yang Maha Esa. Sesuai dengan visi sekolah yaitu "Unggul Spiritual, Iptek Berbudaya Nusantara, Berwawasan Global", kegiatan IMTAQ disekolah bertujuan untuk membekali sikap santun dan sifat yang baik bagi peserta didik.

SMK Negeri 13 Malang mempunyai kekhasan dalam penerapan budaya ketarunaan yang berbeda dengan sekolah lain. Perbedaan itu terletak pada keseimbangan dalam kegiatan ketarunaan dengan peningkatan keimanan. Dalam penelitian Suwarno (2017) tentang "Pengembangan Model Pengelolaan Pembentukan Karakter Melalui Program Pendidikan Ketarunaan di SMK Negeri 2 Sragen" menyebutkan bahwa dalam pelaksanaan latihan dasar ketarunaan di SMK Negeri 2 Sragen, dibentuk berupa struktur komando batalyon. Pada SMK Negeri 13 Malang, juga terdapat struktur staff batalyon yang bertugas dalam pelaksanaan latihan dasar ketarunaan. Selain itu, sebagai hal yang membedakan adalah adanya kerjasama antara sekolah dengan Pangkalan Angkatan Laut (LANAL) Malang sehingga pembina latihan bukan hanya staff batalyon tetapi juga petugas khusus dari LANAL. Hal inilah yang mendasari pentingnya penelitian "Budaya Sekolah Berbasis Ketarunaan Dalam Pembentukan Karakter Peserta 
Didik (Studi Kasus di SMK Negeri 13 Malang)" dilakukan, agar dapat mengetahui dan menjelaskan secara lebih terperinci mengenai budaya sekolah dengan basis ketarunaan yang dipadu dengan peningkatan keimanan bagi peserta didik untuk membentuk karakter peserta didik.

\section{METODE}

Penelitian ini menggunakan pendekatan kualitatif, dengan jenis penelitian studi kasus karena penelitian ini memusatkan perhatian pada suatu kasus yang unik secara intensif dan rinci. Penelitian ini dilakukan di SMK Negeri 13 Malang karena merupakan sekolah kejuruan yang berbasis ketarunaan dengan berlandaskan iman dan taqwa di Kota Malang. Sekolah ini berada tepat di Perumahan Villa Bukit Tidar, Blok A2 No 13, Jl. Villa Bukit Tidar, Merjosari, Kec. Lowokwaru, Kota Malang, Jawa Timur.

Teknik pengumpulan data yang digunakan yaitu wawancara, observasi, dan dokumentasi. Sumber data yang dibutuhkan dalam penelitian ini tentunya yang berkaitan dengan budaya sekolah berbasis ketarunaan dalam pembentukan karakter disiplin peserta didik di SMK Negeri 13 Malang. Dalam memperoleh informasi, pertama dilakukan oleh satu informan kunci, kemudian menemukan informan kedua melalui informasi yang diberikan oleh informan kunci. Begitu juga selanjutnya, hingga peneliti mendapatkan informasi yang relevan dengan seluruh fokus. Kegiatan tersebut disebut snowball sampling yaitu membiarkan data mengalir dari orang- orang yang menjadi subjek dan berada dalam situasi sosial. Melalui beberapa teknik, data penelitian yang diperoleh kemudian dilakukan analisis dengan cara mereduksi data sesuai dengan kebutuhan fokus penelitian. Data yang telah direduksi kemudian disajikan dan ditarik kesimpulannya. Pengecekan keabsahan data dilakukan peneliti untuk mempertanggungjawabkan kebenaran dari data yang telah didapatkan. Keabsahan data dilakukan melalui dengan mengecek/menguji melalui empat kriteria yaitu 1) keterpercayaan; 2) keteralihan; 3) ketergantungan dan 4) kepastian. Dalam kriteria keterpercayaan, terdapat lima cara yang dilakukan yaitu 1) triangulasi; 2) pengecekan anggota; 3) perpanjangan waktu pengamatan; 4) meningkatkan ketekunan dan 5) kecukupan bahan referensi.

\section{HASIL}

\section{Bentuk Budaya Sekolah Berbasis Ketarunaan di SMK Negeri 13 Malang}

Bentuk budaya sekolah berbasis ketarunaan di SMK Negeri 13 Malang terdiri dari budaya akademik, budaya demokratis, dan budaya sosial. Bentuk budaya akademik yang diterapkan di SMK Negeri 13 Malang bertujuan agar peserta didik berpikir, bersikap serta bertindak sesuai dengan teori, dasar hukum serta nilai kebenaran yang teruji. Budaya yang berlangsung berupa, kegiatan literasi, mendengarkan dan membaca asmaul husna dan sholawat, khotmil Qur'an setiap bulan, dan kegiatan kebaktian.

Bentuk budaya demokratis yang diterapkan di SMK Negeri 13 Malang bertujuan agar peserta didik mampu mengakomodasi perbedaan untuk kemajuan serta menerapkan rasa cinta tanah air, toleransi dan semangat kebangsaan. Budaya yang diterapkan yaitu kegiatan apel pagi dan sore, penggunaan seragam taruna, sapa hormat guru dan senior, hormat bendera setiap pukul 6 pagi, lagu nasional dan lagu daerah di sekolah, poster tentang janji taruna dan karakter taruna di area sekolah, dan kegiatan ketarunaan setiap hari Rabu dan Kamis.

Bentuk budaya sosial yang diterapkan di SMK Negeri 13 Malang bertujuan agar peserta didik mampu menerapkan kehidupan sosial yang harmonis antar warga sekolah. Bentuk budaya sosial yang diterapkan berupa, kegiatan sholat shuha, Zuhur dan Ashar berjamaah, kerja bakti setiap bulan, keputrian, lepas sepatu dalam gedungm menghentikan kendaraan dan membuka jaket di luar portal, dan kegiatan istighosah bersama orang tua.

\section{Keunggulan Budaya Sekolah Berbasis Ketarunaan di SMK Negeri 13 Malang}

Keunggulan budaya sekolah meliputi keuntungan yang diperoleh oleh pihak internal dan eksternal sekolah. Pihak internal yaitu peserta didik, guru serta tenaga kependidikan. Bagi peserta didik adalah 
meningkatkan kesadaran disiplin, meningkatnya ketaqwaan kepada Tuhan YME, lebih rajin, memiliki toleransi yang tinggi, bertanggungjawan dalam tugas, percaya diri, memiliki jiwa kepemimpinan dan cinta tanah air. Keuntungan bagi guru yaitu peserta didik yang mudah diarahkan dalam pembelajaran, Pribadi guru dan tenaga kependidikan menjadi lebih bertaqwa kepada Tuhan YME karena pembiasaan sehari-hari, dan peserta didik yang lebih disiplin dalam pengumpulan data yang diminta. Pihak eksternal yaitu orang tua, masyarakat serta dunia usaha dan dunia industri (DU/DI). Bagi orang tua, keuntungan yang didapatkan adalah perasaan bangga terhadap peningkatan karakter baik anaknya, mampu membimbing anak dalam lingkungan yang unggul. Bagi masyarakat, keuntungan yang didapatkan adalah timbulnya standart tampilan peserta didik yang seharusnya ada di lingkungan sosial. Sedangkan keuntunga yang didapatkan oleh pihak dunia usaha dunia industri (DU/DI) yaitu peserta didik dapat menjadi calon tenaga kerja yang memiliki sikap teladan bagi rekannya.

\section{Proses Pembentukan Karakter Peserta Didik Melalui Pelaksanaan Budaya Sekolah di SMK Negeri 13 Malang}

Pembentukan karakter melalui pelaksanaan budaya di SMK Negeri 13 Malang diawali dengan penyiapan lingkungan sekolah dan peserta didik. Lingkungan sekolah yang dimaksud adalah wujud gambaran karakter yang ingin dibentuk pada peserta didik, termasuk didalamnya visi, misi, serta tujuan sekolah serta sarana atau fasilitas yang disediakan oleh sekolah. Peserta didik harus disiapkan sedemikian rupa agar mampu menerima dan melaksanakan budaya sekolah yang ada. Peserta didik yang telah siap kemudian melaksanakan budaya sekolah yang ada dan kemudian mendapatkan nilainilai karakter yang perlu diinternalisasikan dan terbentuk dalam diri peserta didik. Pelaksanaan budaya membutuhkan elemen penujang yang membantu keberlangsungan budaya yang ada. Elemen ini berupa pembentukan karakter sesuai visi misi sekolah, pedoman karakter taruna, strategi dalam pembentukan karakter peserta didik, program afirmasi dan inklusi, fasilitas sekolah dalam pembentukan karakter, keterlibatan orang tua menunjang keberhasilan budaya sekolah dan seluruh elemen bertanggungjawab dalam pelaksanaan budaya sekolah.

Beberapa nilai yang terbentuk dari pelaksanaan budaya sekolah yaitu gemar membaca, rasa ingin tahu, religius, jujur, disiplin, demokratis, tanggung jawab, solidaritas, bersahabat, toleransi, cinta tanah air, nasionalis, semangat kebangsaan, apresiasi budaya bangsa, menghargai prestasi, kerja keras, keberanian, daya juang, mandiri, gotong royong, rela berkorban, peduli lingkungan, cinta damai dan peduli sosial.

\section{Faktor Pendukung Pelaksanaan Budaya Sekolah Berbasis Ketarunaan dalam Pembentukan Karakter Peserta Didik}

Faktor pendukung dalam pelaksanaan budaya sekolah berbasis ketarunaan meliputi pendukung dari pihak internal dan pihak eksternal. Faktor pendukung dari pihak internal yaitu guru yang mengawasi budaya sekolah, keterlibatan seluruh elemen demi keberhasilan pelaksanaan budaya, fasilitas sekolah yang mendukung dan budaya sekolah dan pembelajaran yang seimbang. Faktor pendukung dari pihak eksternal yaitu kerjasama dengan Pangkalan Angkatan Laut (Lanal), fasilitas simulator dari DPR, kerjasama dengan pondok pesantren (Bahlul Magfiroh), Mubhalighh UIN serta asrama Kristen untuk pendidikan agama, serta orang tua mendukung dalam budaya sekolah.

\section{Faktor Penghambat Pelaksanaan Budaya Sekolah Berbasis Ketarunaan dalam Pembentukan Karakter Peserta Didik}

Faktor penghambat dalam pelaksanaan budaya sekolah berbasis ketarunaan meliputi penghambat dari pihak internal dan pihak eksternal. Faktor penghambat dari pihak internal yaitu beberapa guru yang melanggar komitmen, peserta didik yang kurang dapat dibina (dalam keseharian dan penginternalisasian) dan lokasi sekolah yang sulit diakses. Faktor penghambat dari pihak eksternal yaitu orang tua yang tidak melakukan pembiasaan yang baik di rumah. 


\section{Solusi yang Dilakukan untuk Mengatasi Hambatan dalam Pelaksanaan Budaya Sekolah Berbasis Ketarunaan}

Solusi yang dilakukan untuk mengatasi penghambat dalam pelaksanaan budaya sekolah berbasis ketarunaan meliputi solusi dari pihak internal dan pihak eksternal. Solusi dalam mengatasi hambatan dari pihak internal yaitu pelaksanaan evaluasi sekolah, penanganan bertahap dari seluruh elemen, buku saku taruna untuk peserta didik, hukuman bagi pelanggaran, dan adanya asrama sekolah. Solusi dalam mengatasi hambatan dari pihak eksternal yaitu kegiatan sosialisasi dengan orang tua.

\section{PEMBAHASAN}

\section{Bentuk Budaya Sekolah Berbasis Ketarunaan di SMK Negeri 13 Malang}

Bentuk budaya yang diterapkan di SMK Negeri 13 Malang terdiri dari budaya akademik, budaya demokratis, dan budaya sosial. Budaya yang diterapkan memiliki tujuan untuk membentuk karakter pada peserta didik. Budaya sekolah merupakan salah satu cara dalam penguatan pendidikan karakter melalui pembiasaan di lingkungan sekolah. Pembiasaan yang dilakukan sehari-hari di sekolah mampu membentuk karakter pada peserta didik. Sependapat dengan Kementerian Pendidikan dan Kebudayaan Republik Indonesia (2017), penguatan pendidikan karakter berbasis budaya sekolah terfokus pada pembiasaan dan pembentukan budaya yang mempresentasikan nilai-nilai utama pendidikan karakter yang menjadi prioritas satuan pendidikan. Pembiasaan ini terintegrasi dalam keseluruhan kegiatan di sekolah yang tercermin dari suasana dan lingkungan sekolah yang kondusif.

Budaya akademik bertujuan untuk menambah wawasan dan pengetahuan agar peserta didik berpikir, bersikap serta bertindak sesuai dengan teori, dasar hukum serta nilai kebenaran yang teruji. Bentuk budaya akademik yang diterapkan berupa, kegiatan literasi, mendengarkan dan membaca asmaul husna dan sholawat, khotmil Qur'an setiap bulan, dan kegiatan kebaktian. Budaya akademik ini membentuk beberapa karakter pada peserta didik yaitu gemar membaca, rasa ingin tahu, menghargai prestasi, kreatif, mandiri. Sudrajat (2011) menerangkan bahwa kultur akademik memiliki ciri pada setiap keputusan, tindakan, kebijakan serta opini didukung dengan dasar akademik yang kuat dan bermakna merujuk pada teori, dasar hukum, dan nilai kebenaran yang teruji.

Bentuk budaya demokratis yang diterapkan di SMK Negeri 13 Malang bertujuan agar peserta didik mampu mengakomodasi perbedaan untuk kemajuan serta menerapkan rasa cinta tanah air, toleransi dan semangat kebangsaan. Budaya yang diterapkan yaitu kegiatan apel pagi dan sore, penggunaan seragam taruna, sapa hormat guru dan senior, hormat bendera setiap pukul 6 pagi, lagu nasional dan lagu daerah di sekolah, poster tentang janji taruna dan karakter taruna di area sekolah, dan kegiatan ketarunaan setiap hari rabu dan kamis. Budaya demokratis membentuk beberapa karakter pada peserta didik yaitu demokratis, disiplin, jujur, semangat kebangsaan, cinta tanah air, serta toleransi. Sudrajat (2011) berpendapat bahwa kultur demokratis menampilkan corak kehidupan yang mengakomodasi perbedaan untuk bersama membangun kemajuan suatu kelompok maupun bangsa.

Bentuk budaya sosial yang diterapkan di SMK Negeri 13 Malang bertujuan agar peserta didik mampu menerapkan kehidupan sosial yang harmonis antar warga sekolah. Bentuk budaya sosial yang diterapkan berupa, kegiatan sholat dhuha, zuhur dan ashar berjamaah, kerja bakti setiap bulan, keputrian, lepas sepatu dalam gedung, menghentikan kendaraan dan membuka jaket di luar portal, dan kegiatan istighosah bersama orang tua. Budaya sosial membentuk beberapa karakter pada peserta didik yaitu religius, bersahabat, cinta damai, peduli sosial, peduli lingkungan, dan tanggung jawab. Sudrajat (2011) menyatakan bahwa kultur sosial budaya menekankan pada interaksi yang berhubungan dengan orang lain, alam dan interaksi yang diperoleh berdasarkan kebiasaan sehari-hari.

\section{Keunggulan Budaya Sekolah Berbasis Ketarunaan di SMK Negeri 13 Malang}

Budaya sekolah berbasis ketarunaan merupakan salah satu cara dalam mengimplementasikan pendidikan karakter di sekolah melalui kegiatan keseharian di sekolah. Adanya budaya sangatlah penting bagi suatu lembaga pendidikan, budaya dapat terbentuk secara turun temurun ataupun melalui 
pembiasaan yang dilakukan. Dengan adanya budaya, sekolah dapat melakukan adaptasi dalam berbagai kondisi masyarakat serta mampu membentuk karakter warga sekolah terutama karakter peserta didik. Karakter ini dapat terbentuk melalui proses pelaksanaan kegiatan budaya yang ada di sekolah. Budaya yang baik akan mampu membentuk karakter peserta didik yang baik. Sesuai dengan pendapat Zamroni (2011) yang mengemukakan mengenai pentingnya sekolah memiliki budaya, sekolah sebagai suatu organisasi harus memiliki: (1) kemampuan untuk hidup, tumbuh berkembang dan melakukan adaptasi dengan berbagai lingkungan yang ada, dan (2) integrasi internal yang memungkinkan sekolah untuk menghasilkan individu atau kelompok yang memiliki sifat positif.

Budaya sekolah berbasis ketarunaan memiliki makna bahwa sekolah menerapkan prinsip militer dalam kehidupan sehari-hari di sekolah. Sesuai dengan Hasil penelitian Suwarno (2017) menyebutkan bahwa ketarunaan memiliki arti sebagai sistem pendidikan yang menerapkan prinsip-prinsip militer yang bertujuan untuk membentuk karakter. Dengan penerapan prinsip militer ini, tentu sekolah memiliki budaya yang berbeda dengan sekolah reguler pada umumnya. Penerapan prinsip militer ini mampu membuat sekolah memiliki keunggulan yang tidak dimiliki oleh sekolah lain, keunggulan ini tercermin pada keuntungan yang didapatkan oleh warga sekolah. Keuntungan diperoleh oleh pihak internal dan eksternal sekolah. Pihak internal yaitu peserta didik, guru serta tenaga kependidikan. Sedangkan pihak eksternal yaitu orang tua, masyarakat serta dunia usaha dan dunia industri (DU/DI).

Keuntungan yang didapat oleh pihak internal, bagi peserta didik adalah meningkatkan kesadaran disiplin, meningkatnya ketaqwaan kepada Tuhan YME, lebih rajin, memiliki toleransi yang tinggi, bertanggungjawan dalam tugas, percaya diri, memiliki jiwa kepemimpinan dan cinta tanah air. Keuntungan bagi guru yaitu peserta didik yang mudah diarahkan dalam pembelajaran, pribadi guru dan tenaga kependidikan menjadi lebih bertaqwa kepada Tuhan YME karena pembiasaan sehari-hari, dan peserta didik yang lebih disiplin dalam pengumpulan data yang diminta. Keuntungan yang didapat oleh pihak eksternal, bagi orang tua, keuntungan yang didapatkan adalah perasaan bangga terhadap peningkatan karakter baik anaknya, mampu membimbing anak dalam lingkungan yang unggul. Bagi masyarakat, keuntungan yang didapatkan adalah timbulnya standart tampilan peserta didik yang seharusnya ada di lingkungan sosial. Sedangkan keuntunga yang didapatkan oleh pihak dunia usaha dunia industri (DU/DI) yaitu peserta didik dapat menjadi calon tenaga kerja yang memiliki sikap teladan bagi rekannya.

\section{Proses Pembentukan Karakter Pesera Didik melalui Pelaksanaan Budaya di SMK Negeri 13 Malang}

Pembentukan karakter melalui pelaksanaan budaya di SMK Negeri 13 Malang diawali dengan penyiapan peserta didik serta lingkungan sekolah. Peserta didik yang dimaksud adalah anggota masyarakat yang ingin meningkatkan kemampuan serta keterampilan dalam mengasah potensi diri pada jenjang Sekolah Menengah Kejuruan, pengertian ini sesuai dengan ketentuan Undang-Undang RI Nomor 20 Tahun 2003 tentang Sistem Pendidikan Nasional Bab I Pasal 1 Ayat 4, "peserta didik adalah anggota masyarakat yang berusaha mengembangkan dirinya melalui proses pendidikan pada jalur, jenjang, dan jenis pendidikan tertentu. Sedangkan lingkungan sekolah yang dimaksud adalah lingkungan alam, sosial dan budaya yang merupakan wujud gambaran karakter yang ingin dibentuk pada peserta didik, termasuk didalamnya visi, misi, serta tujuan sekolah serta sarana atau fasilitas yang disediakan oleh sekolah. Menurut Hamalik (2009:6) "lingkungan sekolah adalah sebagai tempat mengajar dan belajar. Sebagai suatu lembaga yang menyelenggarakan pengajaran dan kesempatan belajar harus memenuhi bermacammacam persyaratan antara lain: murid, guru, program pendidikan, asrama, sarana dan fasilitas."

Proses selanjutnya merupakan proses pelaksanaan budaya sekolah. Dalam melaksanakan budaya sehari-hari, peserta didik akan mengalami pembentukan terhadap karakternya secara perlahan. Peserta didik melaksanakan seluruh budaya sekolah, termasuk budaya akademik, budaya demokratis serta budaya sosial yang diterapkan di sekolah. Pembiasaan pelaksanaan kegiatan berbasis ketarunaan serta lingkungan sekolah yang kondusif, mampu membentuk pribadi peserta didik yang lebih disiplin. Dalam pelaksanaan kegiatan, dibutuhkan elemen penunjang untuk membantu keberlangsungan budaya yang ada. Elemen ini berupa pembentukan karakter sesuai visi misi sekolah, pedoman karakter taruna, 
strategi dalam pembentukan karakter peserta didik, program afirmasi dan inklusi, fasilitas sekolah dalam pembentukan karakter, keterlibatan orang tua menunjang keberhasilan budaya sekolah dan seluruh elemen bertanggungjawab dalam pelaksanaan budaya sekolah.

Pembentukan karakter pada peserta didik dilandaskan pada visi dan misi SMK Negeri 13 Malang. Visi dan misi ini mencerminkan karakter yang akan terbentuk pada peserta didik, karakter yang telah terinternalisasi pada peserta didik ini menjadi salah satu bentuk terwujudnya visi dan misi sekolah. Seperti hasil riset yang dilakukan oleh Sukaningtyas, dkk (2017) bahwa "visi, misi, dan tujuan sekolah saling terkait. Pencapaian visi dan misi sekolah merupakan makna pencapaian mutu sekolah. Mutu sekolah yang diharapkan dinyatakan dalam pernyataan visi dan misi." Selain visi dan misi, SMK Negeri 13 Malang juga memiliki pedoman karakter taruna yang digunakan sebagai dasar dalam pembentukan karakter. Pedoman ini terdiri dari 5 karakter wajib taruna, 7 janji taruna dan 7 pantangan taruna.

Hasil akhir yang didapatkan peserta didik melalui pembiasaan dari budaya sekolah yang ada merupakan nilai-nilai karakter yang terinternalisasikan dan terbentuk dalam diri peserta didik. Nilai yang didapatkan kemudian mampu menjadi karakter peserta didik, nilai ini sangat beragam dan dihasilkan dari proses pelaksanaan pembiasaan dan kegiatan yang dilakukan dalam kehidupan sehari-hari peserta didik di sekolah. Nilai ini sesuai dengan nilai luruh yang wajib dimiliki oleh generasi bangsa menurut Kementerian Pendidikan Nasional Republik Indonesia (2010) yang mencakup nilai berikut ini: 1) religius, 2) jujur, 3) toleransi, 4) disiplin, 5) kerja keras, 6) kreatif, 7) mandiri, 8) demokratis, 9) rasa ingin tahu, 10) semangat kebangsaan, 11) cinta tanah air, 12) menghargai prestasi, 13) bersahabat/komunikatif, 14) cinta damai, 15) gemar membaca, 16) peduli lingkungan, 17) peduli sosial, 18) tanggung jawab.

\section{Faktor Pendukung Pelaksanaan Budaya Sekolah Berbasis Ketarunaan dalam Pembentukan Karakter Peserta Didik}

Faktor pendukung dalam pelaksanaan budaya sekolah berbasis ketarunaan merupakan hal-hal yang berdampak positif pada pelaksanaan budaya sekolah. Faktor ini meliputi pendukung budaya sekolah dari pihak internal dan pihak eksternal. Menurut Mulyasa (2012: 104) secara umum faktorfaktor penentu yang perlu diperhatikan dalam budaya sekolah adalah sebagai berikut. (1) Tujuan dan sasaran pendidikan nasional dan pembangunan bukan hanya untuk menciptakan golongan elit dan kaum intelektuan, melainkan membentuk manusia Indonesia secara utuh. (2) Peserta didik merupakan subjek sekaligus objek pendidikan. (3) Mendidik merupakan pekerjaan profesional, memberikan petunjuk bahwa tidak setiap orang dapat melaksanakan profesi mendidik (pendidik). (4) Isi pendidikan merupakan segala pengalaman yang harus dimiliki peserta didik. (5) Keberhasilan pendidikan sangat ditentukan oleh kelengkapan fasilitas dan sumber belajar.

Faktor pendukung dari pihak internal yaitu guru yang mengawasi budaya sekolah, keterlibatan seluruh elemen demi keberhasilan pelaksanaan budaya, fasilitas sekolah yang mendukung dan budaya sekolah dan pembelajaran yang seimbang. Faktor pendukung dari pihak eksternal yaitu kerjasama dengan Pangkalan Angkatan Laut (Lanal), fasilitas simulator dari DPR, kerjasama dengan pondok pesantren (Bahrul Magfiroh), Mubhaligh UIN dan Asrama Kristen untuk pendidikan agama, serta orang tua mendukung dalam budaya sekolah.

\section{Faktor Penghambat Pelaksanaan Budaya Sekolah Berbasis Ketarunaan dalam Pembentukan Karakter Peserta Didik di SMK Negeri 13 Malang}

Faktor penghambat dalam pelaksanaan budaya sekolah berbasis ketarunaan merupakan beberapa hal yang dapat menghambat keberlangsungan budaya yang ada di sekolah. Faktor ini meliputi penghambat dari pihak internal dan pihak eksternal. Faktor penghambat dari pihak internal yaitu beberapa guru yang melanggar komitmen, peserta didik yang kurang dapat dibina (dalam keseharian dan penginternalisasian) dan lokasi sekolah yang sulit diakses. Faktor penghambat dari pihak eksternal yaitu orang tua yang tidak melakukan pembiasaan yang baik di rumah. Sebagai pendukung hasil penelitian ini, temuan dari Andiarini (2018) menyebutkan bahwa penghambat dalam pelaskanaan pendidikan pendidikan karakter di sekolah meliputi aspek peserta didik, guru, sarana dan prasarana serta orang tua peserta didik. 


\section{Solusi yang Dilakukan untuk Mengatasi Hambatan dalam Pelaksanaan Budaya Sekolah Berbasis Ketarunaan}

Solusi yang diambil untuk mengatasi hambatan dalam pelaksanaan budaya sekolah berbasis ketarunaan merupakan jalan keluar dari permasalahan yang menghambat pelaksanaan budaya sekolah. Kata solusi bermakna sebagai penyelesaian atau pemecahan masalah dengan kata lain sebagai jalan keluar. Menurut Metallidou dalam Mataka (2009) pemecahan masalah merupakan perilaku terarah yang membutuhkan representasi mental yang tepat dan penerapan selanjutnya dari metode atau strategi tertentu untuk memulai dari awal agar tujuan yang diinginkan dapat tercapai. Solusi ini terdiri dari pihak internal dan pihak eksternal. Solusi dalam mengatasi hambatan dari pihak internal yaitu pelaksanaan evaluasi sekolah, penanganan bertahap dari seluruh elemen, buku saku taruna untuk peserta didik, hukuman bagi pelanggaran, dan adanya asrama sekolah. Solusi dalam mengatasi hambatan dari pihak eksternal yaitu kegiatan sosialisasi dengan orang tua.

\section{KESIMPULAN}

Budaya sekolah sekolah berbasis ketarunaan di SMK Negeri 13 Malang berlangsung dengan adanya keseimbangan antara pembiasaan disiplin dengan peningkatan iman dan taqwa peserta didik. Keseimbangan ini digambarkan pada bentuk budaya yang terdiri dari 3 kategori yaitu budaya akademik, budaya demokratis dan budaya sosial. Kegiatan dan pembiasaan yang dilakukan di SMK Negeri 13 Malang meliputi kegiatan literasi, mendengarkan dan membaca asmaul husna dan sholawat, khotmil Qur'an setiap bulan, kegiatan kebaktian, kegiatan apel pagi dan sore, penggunaan seragam taruna, sapa hormat guru dan senior, hormat bendera setiap pukul 6 pagi, lagu nasional dan lagu daerah di sekolah, poster tentang janji taruna dan karakter taruna di area sekolah, kegiatan ketarunaan setiap hari Rabu dan Kamis, kegiatan sholat dhuha, zuhur dan ashar berjamaah, kerja bakti setiap bulan, keputrian, lepas sepatu dalam gedung, menghentikan kendaraan dan membuka jaket di luar portal, dan kegiatan istighosah bersama orang tua. Keunggulan yang didapat dari pelaksanaan budaya sekolah ini meliputi keuntungan yang diperoleh oleh pihak internal dan eksternal sekolah. Pihak internal yaitu peserta didik, guru, dan tenaga kependidikan. Pihak eksternal yaitu orang tua, masyarakat, dan dunia usaha serta dunia industri (DU/DI).

Proses pembentukan karakter peserta didik melalui pelaksanaan budaya di SMK Negeri 13 Malang diawali dengan penyiapan peserta didik serta lingkungan sekolah. Proses selanjutnya merupakan proses pelaksanaan budaya sekolah. Hasil akhir yang didapatkan peserta didik melalui pembiasaan dari budaya sekolah yang ada merupakan nilai-nilai karakter yang terinternalisasikan dan terbentuk dalam diri peserta didik. Pelaksanaan budaya membutuhkan elemen penujang yang membantu keberlangsungan budaya yang ada. Elemen ini berupa pembentukan karakter sesuai visi misi sekolah, pedoman karakter taruna, strategi dalam pembentukan karakter peserta didik, program afirmasi dan inklusi, fasilitas sekolah dalam pembentukan karakter, keterlibatan orang tua menunjang keberhasilan budaya sekolah dan seluruh elemen bertanggungjawab dalam pelaksanaan budaya sekolah. Faktor pendukung pelaksanaan budaya sekolah berbasis ketarunaan ini meliputi faktor pendukung dari pihak internal dan pihak eksternal.

Faktor pendukung dari pihak internal yaitu guru yang mengawasi budaya sekolah, keterlibatan seluruh elemen demi keberhasilan pelaksanaan budaya, fasilitas sekolah yang mendukung dan budaya sekolah dan pembelajaran yang seimbang. Faktor pendukung dari pihak eksternal yaitu kerjasama dengan Pangkalan Angkatan Laut (Lanal), fasilitas simulator dari DPR, kerjasama dengan Pondok Pesantren (Bahrul Magfiroh), Mubhaligh UIN, dan Asrama Kristen untuk pendidikan agama, dan orang tua mendukung dalam budaya sekolah. Faktor penghambat dalam pelaksanaan budaya sekolah berupa penghambat dari pihak internal dan pihak eksternal. Faktor penghambat dari pihak internal yaitu beberapa guru yang melanggar komitmen, peserta didik yang kurang dapat dibina (dalam keseharian dan penginternalisasian) dan lokasi sekolah yang sulit diakses. Faktor penghambat dari pihak eksternal yaitu orang tua yang tidak melakukan pembiasaan yang baik di rumah. Solusi yang dilakukan untuk mengatasi hambatan dalam pelaksanaan budaya meliputi solusi dari pihak internal dan pihak eksternal. 
Solusi dalam mengatasi hambatan dari pihak internal yaitu pelaksanaan evaluasi sekolah, penanganan bertahap dari seluruh elemen, buku saku taruna untuk peserta didik, hukuman bagi pelanggaran, dan adanya asrama sekolah. Solusi dalam mengatasi hambatan dari pihak eksternal yaitu kegiatan sosialisasi dengan orang tua.

\section{DAFTAR RUJUKAN}

Andiarini, S. E. 2018. Implementasi Program Penguatan Pendidikan Karakter Melalui Kegiatan Pembiasaan Dalam Peningkatan Mutu Sekolah. Jurnal Administrasi dan Manajemen Pendidikan, 1(2),238-244.

Hamalik, Oemar. 2009. Kurikulum dan Pembelajaran. Jakarta: Bumi Aksara.

Kementerian Pendidikan dan Kebudayaan Republik Indonesia. 2017. Konsep dan Pedoman Penguatan Pendidikan Karakter. Jakarta: Tim PPK Kemendikbud.

Kementerian Pendidikan Nasional, Badan Penelitian dan Pengembangan Pusat Kurikulum. 2010. Pengembangan Pendidikan Budaya dan Karakter Bangsa. Jakarta: Badan Penelitian dan Pengembangan Pusat Kurikulum.

Mataka, L.M. etc. 2014. The effect of using an explicit general problem solving teaching approach on elementary preservice teachers 'ability to solve heat transfer problems. International Journal of Education in Mathematics, Science and Technology, 2(3), 164-174. (Online), (http://ijemst.com/issues/2_3_1_Mataka_Cobern_Grunert Mutambuki_Akom.pdf), diakses pada 25 Juni 2018.

Mukhtar. 2013. Metode Praktis Penelitian Deskripif Kualitatif. Jakarta: Referensi.

Mulyasa, E. 2012. Manajemen Pendidikan Karakter. Jakarta: Bumi Aksara.

Sudrajat, A. 2011. “Mengapa pendidikan karakter?”. Jurnal Pendidikan Karakter. Volume I. Nomor 1. (Online), (http://journal.uny.ac.id/index.php/jpka/ article/view/1316), diakses 25 April 2018

Sukaningtyas, Dwi., dkk. 2017. Pengembangan Kapasitas Manajemen Sekolah dalam Membangun Pemahaman Visi dan Misi. Jurnal Cakrawala Pendidikan (2). Dari https://media.neliti.com/media/publications/95462ID-pengembangan-kapasitas-manajemen-sekolah.pdf.

Suryanto. 2016. “Mobosti” Pola Pendidikan Jitu Bagi SMK untuk Siap Menghadapi Persaingan Ketenagakerjaan. (Online), (https://anzdoc.com/mabosti-pola-pendidikan-jitu-bagi-smk-untuk-siap-menghadapi-.html), diakses 18 Maret 2018

Suwarno. 2017. Pengembangan Model Pengelolaan Pembentukan Karakter Melalui Program Pendidikan Karakter di SMK Negeri 2 Sragen. Tesis, Surakta: Pascasarjana Universitas Muhammadiyah Surakarta.

Undang-Undang Republik Indonesia Nomor 20 Tahun 2003 tentang Sistem Pendidikan Nasional. 2006. Bandung: Citra Umbara.

Zamroni. 2011. Dinamika Peningkatan Mutu. Yogyakarta: Gavin Kalam Utama. 